\title{
Neurotensin Decreases the Proinflammatory Status of Human Skin Fibroblasts and Increases Epidermal Growth Factor Expression
}

\author{
Lucília Pereira da Silva, ${ }^{1,2}$ Bruno Miguel Neves, ${ }^{2,3}$ Liane Moura,, \\ Maria Teresa Cruz, ${ }^{2,3}$ and Eugénia Carvalho ${ }^{2,4}$ \\ ${ }^{1}$ Faculdade de Ciências e Tecnologia, Universidade de Coimbra, 3000-456 Coimbra, Portugal \\ ${ }^{2}$ Centro de Neurociências e Biologia Celular, Universidade de Coimbra, 3004-504 Coimbra, Portugal \\ ${ }^{3}$ Faculdade de Farmácia, Universidade de Coimbra, 3000-548 Coimbra, Portugal \\ ${ }^{4}$ Associação Portuguesa de Diabetes (APDP), 1250-189 Lisboa, Portugal \\ Correspondence should be addressed to Eugénia Carvalho; ecarvalh@cnc.uc.pt
}

Received 30 May 2014; Revised 14 July 2014; Accepted 15 July 2014; Published 11 August 2014

Academic Editor: Francesco Maione

Copyright (C) 2014 Lucília Pereira da Silva et al. This is an open access article distributed under the Creative Commons Attribution License, which permits unrestricted use, distribution, and reproduction in any medium, provided the original work is properly cited.

\begin{abstract}
Fibroblasts colonization into injured areas during wound healing (WH) is responsible for skin remodelling and is also involved in the modulation of inflammation, as fibroblasts are immunologically active. Herein, we aimed to determine neurotensin effect on the immunomodulatory profile of fibroblasts, both in homeostatic and inflammatory conditions. Neurotensin mediated responses occurred through NTR1 or NTR3 receptors, while under inflammatory conditions NTR1 expression increase seemed to modulate neurotensin responses. Among different immunomodulatory genes, CCL11, IL-8, and IL-6 were the most expressed genes, while CCL4 and EGF were the less expressed genes. After neurotensin exposure, IL- 8 mRNA expression was increased while CCL11 was decreased, suggesting a proinflammatory upregulation and chemoattractant ability downregulation of fibroblasts. Under inflammatory conditions, gene expression was significantly increased. After neurotensin exposure, CCL4 and IL-6 mRNA expression were decreased while CCL11 was increased, suggesting again a decrease in the chemoattractant capacity of fibroblasts and in their proinflammatory status. Furthermore, the expression of EGF, a crucial growth factor for skin cells proliferation and $\mathrm{WH}$, was increased in all conditions. Overall, neurotensin, released by nerve fibers or skin cells, may be involved in the decrease of the chemotaxis and the proinflammatory status in the proliferation and remodelling phases of $\mathrm{WH}$.
\end{abstract}

\section{Introduction}

Neuropeptides can be produced by skin cells or be released by peripheral nerves into the skin, where they bind to respective receptors stimulating different signalling pathways and cellular responses $[1,2]$. Within the cellular responses and events that can be modulated in the skin by neuropeptides, inflammatory processes are some of the most important. However, the role of neurotensin (NT) in the modulation of skin inflammation is still unclear.

The first report demonstrating NT-positive fibbers in the skin was in 1983 [3] and it was later confirmed by Donelan et al. in 2006 [4]. The interest in NT first appeared when its influence on the pathogenesis of skin disorders exacerbated by stress was discovered [5]. In fact, it has been observed that in many skin disorders worsened by stress, the number and activation status of mast cells increase. Accordingly, NT has been shown to increase the number and activation of mast cells in a skin pathogenesis, such as psoriasis [6], which is in agreement with several other reports showing that mast cell degranulation is triggered by stress and via neurotensin [7-9]. Moreover, skin vascular permeability induced by corticotropin-releasing hormone (CRH) on mast cells has been shown to occur through a neurotensin-dependent mechanism [4]. In fact, human mast cells are able to synthesize a neurotensin precursor, secrete 
bioactive NT-like peptide(s), and express NT receptor NTS1 [10]. Besides mast cells, neurotensin has also been shown to enhance the chemotaxis capacity of lymphocytes and to limit the growth of cutaneous T-cell lymphoma tumor cells [11]. Most recently, we have demonstrated that NT can modulate inflammatory events on a skin dendritic cell line [12]. Fetal-skin dendritic cells expressed both NTR1 and NTR3 and neurotensin was able to downregulate the activation of inflammatory signalling pathways and the expression of cytokines IL-6, TNF- $\alpha$, and IL-10, as well as vascular endothelial growth factor (VEGF), while upregulating the survival pathway ERK and epidermal growth factor (EGF) expression [12].

In spite of these results not much has been studied regarding NT effects in fibroblasts. Therefore, in the present study we used a cell line established from the skin of normal newborn human foreskin fibroblasts. Fibroblasts are a heterogeneous population of cells of mesenchymal origin which support the development, repair, and homeostasis of their resident tissue. Dermal fibroblasts play a key role in extracellular matrix (ECM) deposition, epithelial-mesenchymal interactions, and wound healing [13]. They also contribute to the immune regulation of the skin, producing and releasing chemokines IL-8 and CCL5, cyclooxygenases, and prostanoids, after activation by inflammatory agents, such as bacterial agents [14]. By using this cell line, we intended to decrease the variability of the donors, although lacking the variability of skin from different body locations. Using fibroblasts from the foreskin ensures the use of cells from a skin area replenished of a rich and complex network of nerves with neurophysiologic parameters $[15,16]$.

The main aim of this work was to unravel the effect of neurotensin and its chemoattractant capacity in newborn foreskin fibroblasts, in both homeostatic and inflammatory conditions, in order to understand the possible physiological role of this neuropeptide in skin wound healing as well as speculate about the role of this neuropeptide in other skin pathologies.

\section{Materials and Methods}

2.1. Materials. Lipopolysaccharide (LPS) from Escherichia coli (serotype 026:B6) was obtained from Sigma Chemical Co. (St. Louis, MO, USA), NT was obtained from Bachem (Weil am Rhein, Germany), 30\% Acrylamide/BisSolution $29: 1$, TEMED, and SYBR Green were obtained from BioRad, and High Capacity cDNA Reverse Transcription kit was obtained from Applied Biosystems.

The protease inhibitor cocktail (Complete Mini) and the phosphatase inhibitor cocktail (PhosSTOP) were obtained from Roche (Carnaxide, Portugal). Bicinchoninic acid (BCA) kit assay was obtained from Novagen. The polyvinylidene difluoride (PVDF) membranes and the antibody against $\beta$-actin were purchased from Millipore Corporation (Bedford, MA, USA). The polyclonal antibodies against NTR1(H130), NTR2(H-19), and NTR3(H-300) were purchased from Santa Cruz (Frilabo), references sc-15311, sc-31696, and sc30217, respectively. The alkaline phosphatase-linked secondary antibody and the enhanced chemifluorescence (ECF) reagent were obtained from GE Healthcare (Carnaxide, Portugal). The Vectashield mounting medium was purchased from Vector Inc. (Burlingame, CA, USA), the Alexa Fluor 488 antibody was purchased from Molecular Probes (Eugene, OR, USA), and the Alexa Fluor 555 phalloidin antibody was purchased from Invitrogen (Barcelona, Spain). TRIzol was obtained from Invitrogen; diethyl pyrocarbonate (DEPC) was acquired from AppliChem. Methanol, ethanol, and isopropanol were obtained from Merck. All primers were obtained from MWG Biotech (Ebersberg, Germany). All other reagents were purchased from Sigma Chemical Co.

2.2. Culture of the BJ Cell Line. The BJ cell line (ATCC number CRL-2522) was kindly supplied by Paula Marques and João Malva (Life Sciences Department and Center for Neurosciences and Cell Biology, Coimbra University, Portugal). This cell line was established from skin taken from normal newborn human foreskin fibroblasts. The BJ cell line has the capacity to proliferate to a maximum of 72 population doublings before the onset of senescence.

BJ cells were cultured in endotoxin-free Dulbecco's modified eagle medium (DMEM) supplemented with $10 \%(\mathrm{v} / \mathrm{v})$ of inactivated fetal calf serum, $3.02 \mathrm{~g} / \mathrm{l}$ sodium bicarbonate, $100 \mathrm{U} / \mathrm{mL}$ penicillin, $100 \mu \mathrm{g} / \mathrm{mL}$ streptomycin, and $30 \mathrm{mM}$ of glucose, in a humidified incubator with $5 \% \mathrm{CO}_{2} / 95 \%$ air, at $37^{\circ} \mathrm{C}$. BJ fibroblasts have a doubling time of about $72 \mathrm{~h}$ and were used after reaching 80-90\% confluence, which occurred approximately every 7 days. Along the experiments, cells were monitored by microscopic observation in order to detect any morphological change.

2.3. Western Blot. The cells (a confluent $75 \mathrm{~cm}^{2}$ flask) were washed with ice-cold PBS and harvested in a sonication buffer. Cell lysates and protein quantification were performed as previously described [12]. NTR1, NTR2, and NTR3 levels were evaluated by Western blots. Proteins were separated by electrophoresis and transferred to PVDF membrane, as previously described [12]. The immune complexes were detected by membrane exposure to the ECF reagent, followed by scanning for blue excited fluorescence on the VersaDoc (BioRad Laboratories, Amadora, Portugal). Membranes were stripped and reprobed with the antibody for $\beta$-actin. The generated signals were analysed using the Image-Quant TL software.

2.4. RNA Extraction. Cells $\left(8 \times 10^{5}\right)$ were plated in $60 \mathrm{~mm}$ dishes in a final volume of $6 \mathrm{~mL}$ and were treated with $10 \mathrm{nM}$ of NT during $30 \mathrm{~h}$, or pretreated with $10 \mathrm{nM}$ of NT during $24 \mathrm{~h}$, and then stimulated with $1 \mu \mathrm{g} / \mathrm{mL}$ of LPS during $6 \mathrm{~h}$, treated for $6 \mathrm{~h}$ with LPS, or left untreated (control). Total RNA was isolated from these cells with TRIzol according to the manufacturer's instructions. The RNA concentration was determined by OD260 measurement using a Nanodrop spectrophotometer (Wilmington, DE, USA). RNA was stored in RNA Storage Solution (Ambion, Foster City, CA, USA) at $-80^{\circ} \mathrm{C}$.

2.5. Real-Time RT-PCR. One microgram of total RNA was reverse-transcribed using High Capacity cDNA Reverse 
TABle 1: Primer sequences for targeted cDNAs.

\begin{tabular}{|c|c|c|}
\hline Primer & $5^{\prime}-3^{\prime}$ sequence (F: forward; R: reverse) & RefSeqID \\
\hline HPRT1 & $\begin{array}{l}\text { F: TGACACTGGCAAAACAATG } \\
\text { R: GGCTTATATCCAACACTTCG }\end{array}$ & NM_000194 \\
\hline NT & $\begin{array}{l}\text { F: GCATACATCAAAGATTAGT } \\
\text { R: TAAAGCAGTAGGAAGTTT }\end{array}$ & NM_006183 \\
\hline NTR1 & $\begin{array}{l}\text { F: GTCGTCATACAGGTCAAC } \\
\text { R: GATGATGGTGTTCAGGAC }\end{array}$ & NM_002531 \\
\hline NTR2 & $\begin{array}{l}\text { F: GCAAGAATGAACAGAACA } \\
\text { R: GAATGATTAGTGATGAGGTT }\end{array}$ & NM_012344 \\
\hline NTR3 & $\begin{array}{l}\text { F: TGGGTTGGAGATAGCACTGG } \\
\text { R: ACGACTTCCTCCAGACACCT }\end{array}$ & NM_002959 \\
\hline IL-1 $\beta$ & $\begin{array}{l}\text { F: GCTTGGTGATGTCTGGTC } \\
\text { R: GCTGTAGAGTGGGCTTATC }\end{array}$ & NM_000576 \\
\hline IL-6 & $\begin{array}{l}\text { F: TCTGGATTCAATGAGGAGACTTG } \\
\text { R: TCACTACTCTCAAATCTGTTCTGG }\end{array}$ & NM_000600 \\
\hline IL-8 & $\begin{array}{l}\text { F: CTTTCAGAGACAGCAGAG } \\
\text { R: CTAAGTTCTTTAGCACTCC }\end{array}$ & NM_000584 \\
\hline CCL11 & $\begin{array}{l}\text { F: ACCAGAGCCTGAGTGTTG } \\
\text { R: TGCCCTTTGGACTGATAATGA }\end{array}$ & NM_002986 \\
\hline CCL4 & $\begin{array}{l}\text { F: CGCCTGCTGCTTTTCTTACAC } \\
\text { R: CAGACTTGCTTGCTTCTTTTGG }\end{array}$ & NM_002984 \\
\hline CCL5 & $\begin{array}{l}\text { F: CAGTGAGCTGAGATTGTG } \\
\text { R: TTTGTTGTTGTTGTTGTGA }\end{array}$ & NM_002985 \\
\hline EGF & $\begin{array}{l}\text { F: TCAGAAGATAACATTACAGAAT } \\
\text { R: AATACACCGAGCATACAT }\end{array}$ & NM_001178130 \\
\hline
\end{tabular}

Transcription (RT), from Applied Biosystems. Real-time RTPCR was performed in a $20 \mu \mathrm{L}$ volume containing $2.5 \mu \mathrm{L}$ cDNA (25 ng), $10 \mu \mathrm{L} 2 \mathrm{X}$ SYBR Green Supermix, $2 \mu \mathrm{L}$ of each primer $(250 \mathrm{nM})$, and $1 \mu \mathrm{L}$ of $\mathrm{H}_{2} \mathrm{O}$ PCR grade. Samples were denatured at $95^{\circ} \mathrm{C}$ for $3 \mathrm{~min}$. Subsequently, 40 cycles were run for $10 \mathrm{sec}$ at $95^{\circ} \mathrm{C}$ for denaturation, $30 \mathrm{sec}$ at the appropriate annealing temperature, and $30 \mathrm{sec}$ at $72^{\circ} \mathrm{C}$ for elongation. Real-time RT-PCR reactions were run in duplicate for each sample on a Bio-Rad My Cycler iQ5. After amplification, a threshold was set for each gene and Ct-values were calculated as previously described [12].

Primers were designed using Beacon Designer Software v7.2, from Premier Biosoft International, and thoroughly tested. Primer sequences are given in Table 1 . The results were normalized using a reference gene, hypoxanthine phosphoribosyltransferase 1 (HPRT-1). This reference gene was previously validated in our lab [17] and its expression did not suffer variations upon BJ cell line stimulation with LPS and NT.

2.6. Immunocytochemistry Assay. Cells $\left(2 \times 10^{5}\right)$ were cultured in 24-well plates containing circular glass lamella on the bottom. Cells were washed with ice-cold PBS, fixed with $4 \%$ paraformaldehyde in PBS for $10 \mathrm{~min}$, and then permeabilized with $0.1 \%$ Triton X-100 in PBS containing $200 \mathrm{mM}$ glycine for $5 \mathrm{~min}$. After a blocking step with PBS/1\% BSA for $30 \mathrm{~min}$, cells were incubated overnight with antibodies against NTR1, NTR2, and NTR3 (1:100 in PBS containing 0.1\% BSA). After washing with PBS, cells were incubated with Alexa Fluor 488conjugated goat anti-rabbit antibody $(1: 500)$ and Alexa Fluor
555 phalloidin antibody $(1: 500)$ for $30 \mathrm{~min}$ at room temperature. After a washing step, cells were then incubated for $1 \mathrm{~min}$ with DAPI $(0.1 \mu \mathrm{g} / \mathrm{mL}$ in PBS $)$ and mounted with Vectashield medium to reduce photobleaching. For image acquisition, fluorescence labelling was visualized using a fluorescence microscope-Zeiss Axiovert 200-and images captured with a coupled AxioCam HR camera. In each experiment, the optimal acquisition parameters were defined for the control cells and maintained for all the other conditions within the same experiment.

2.7. Statistical Analysis. The results were statistically analysed using the nonparametric Kruskall-Wallis test followed by Dunn's posttest, using Graphpad software. Results are presented as mean \pm SD and the significance level was ${ }^{*} P<0.05$, ${ }^{* *} P<0.01$, and ${ }^{* * *} P<0.001$.

\section{Results}

3.1. Expression of Neurotensin and Its Receptors on Skin Fibroblasts. BJ cells do not constitutively express neurotensin, under either basal conditions or LPS stimulation (data not shown).

The expression of neurotensin receptors, namely, NTR1, NTR2, and NTR3, was determined by real-time RT-PCR, Western blot, and immunocytochemistry analyses. BJ cells constitutively express the genes for NTR1, NTR2, and NTR3, with NTR2 being the most abundant, as shown in Figure 1(A). 


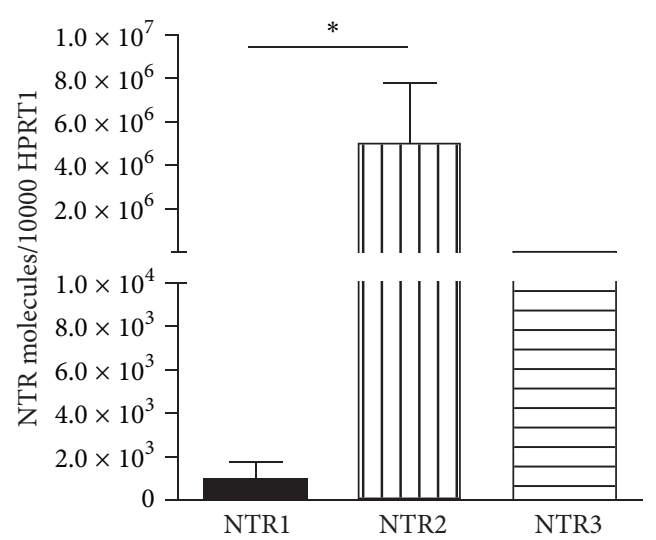

(A) Neurotensin receptors gene expression

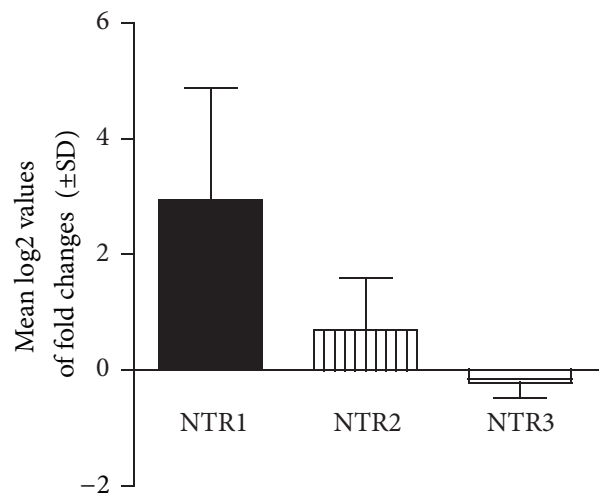

(C) The effect of LPS in the gene expression of neurotensin in receptors

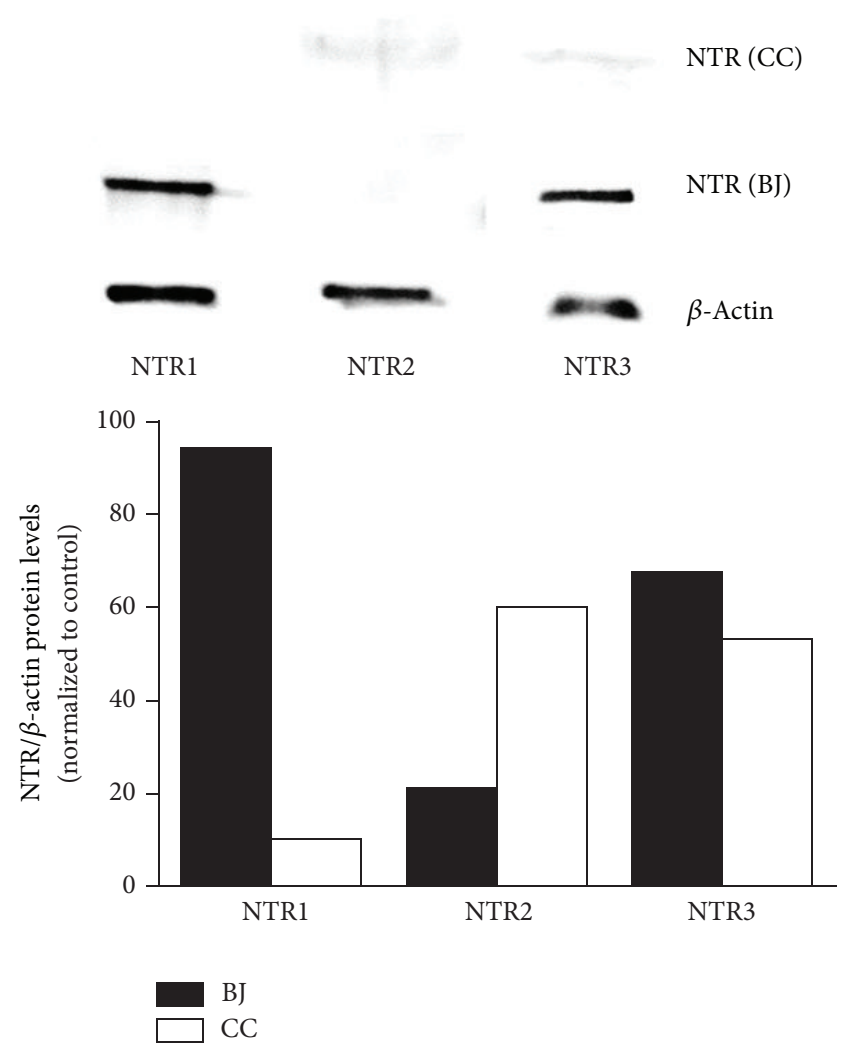

(B) Neurotensin receptors protein expression

FIGURE 1: Neurotensin receptor mRNA and protein expression. Cells were maintained in medium $(\mathrm{A}, \mathrm{B})$ or treated with $1 \mu \mathrm{g} / \mathrm{mL}$ of $\mathrm{LPS}$ for $6 \mathrm{~h}(\mathrm{C})$, at $37^{\circ} \mathrm{C}$, with $5 \% \mathrm{CO}_{2}$. Total RNA was isolated and retrotranscribed as indicated in Section 2 . The mRNA levels were assessed by quantitative real-time RT-PCR. Gene expression is indicated as genes studied/10,000 molecules of the reference gene HPRT1 (A) or mean $\log 2$ values of fold changes relative to the control $(\mathrm{C})$. Each value represents the mean \pm SD from three independent experiments $\left({ }^{*} P<0.05\right.$; Kruskall-Wallis test followed by Dunn's multiple comparison posttest). Cells extracts from untreated BJ cells (BJ) and from the murine cortical cortex (CC) were subjected to Western blot analysis (B) using NTR1, NTR2, and NTR3 antibodies, with normalization to $\beta$-actin. The blot shown is representative of 3 independent experiments yielding similar results.

However, only the NTR1 and NTR3 were effectively transduced to protein, as observed in Figure 1(B), indicating possible cellular posttranscription modification. Brain homogenates from the cortical cortex of mice were used as positive controls for NTR reactivity, since they express all neurotensin receptors, as determined by Western blot analysis (Figure 1(B)).

In addition, the expression of neurotensin receptors was studied under inflammatory conditions. The stimulation of BJ cells with LPS for $6 \mathrm{~h}$ caused an increase in NTR1 and NTR2 gene expression of $2.9 \pm 1.9-\left({ }^{*} P<0.05, n=3\right)$ and $0.7 \pm 0.9$ - $(n=3)$ fold above control, respectively. However, the expression of NTR3 slightly diminished by $0.2 \pm 0.3-$ $(n=3)$ fold, as shown in Figure 1(C).

Neurotensin receptor localization was measured in these cells and it was verified that NTR1 is localized at the cell membrane, in the cytoplasm and in the nucleus, while NTR3 is mainly found in the nucleus (Figure 2).

3.2. Modulation of Gene Expression in Fibroblasts by LPS. To evaluate the expression of different genes under homeostatic conditions and upon $6 \mathrm{~h}$ of LPS exposure, real-time RT-PCR was performed for CCL4, CCL5, CCL11, IL-8, IL-1 $\beta$, IL-6, and epidermal growth factor (EGF).

Nonstimulated BJ cells constitutively expressed all chemokines, cytokines, and the growth factor EGF, with IL-6, IL-8, and CCL11 being the most expressed genes, by $1.6 \times 10^{4} \pm 1.1 \times 10^{4}\left(^{\# \#}<0.01, n=4\right), 2.8 \times 10^{4} \pm 1.9 \times 10^{4}$ $(\# \# \#+0.001, n=4)$, and $2.5 \times 10^{4} \pm 1.7 \times 10^{4}\left(^{\# \# \#}<0.01\right.$, $n=4)$, respectively, relative to HPRT1 gene expression, while CCL4 was barely expressed, by $6.4 \pm 5.0(n=4)$, relative to HPRT1 gene expression (Figure 3). When stimulated with 


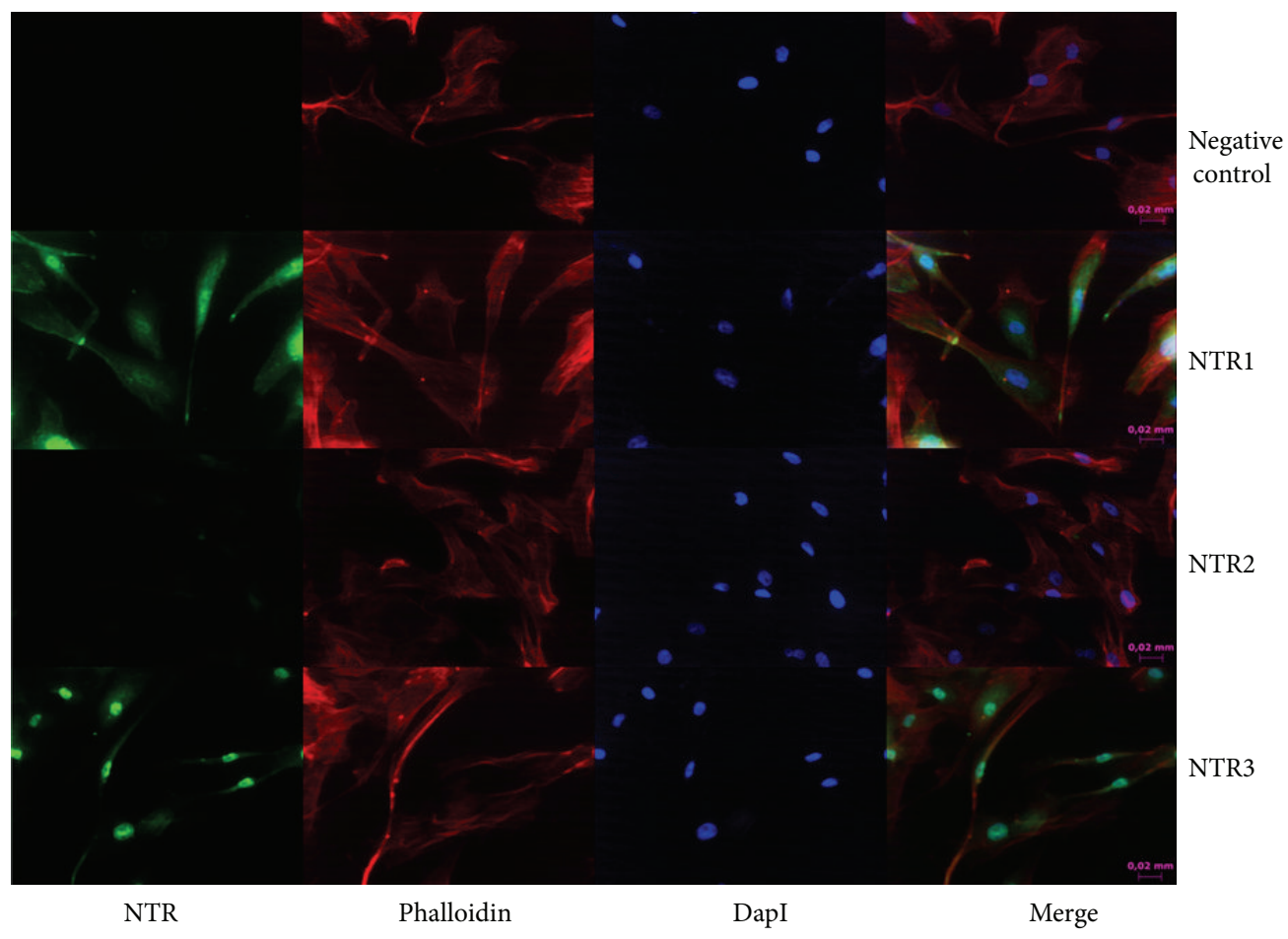

FIGURE 2: Neurotensin receptor localization. Cells were subjected to immunocytochemistry analysis as described in Section 2 using NTR1, NTR2, and NTR3 antibodies.

Cytokines, chemokines, and growth factor expression in homeostatic and inflammatory conditions

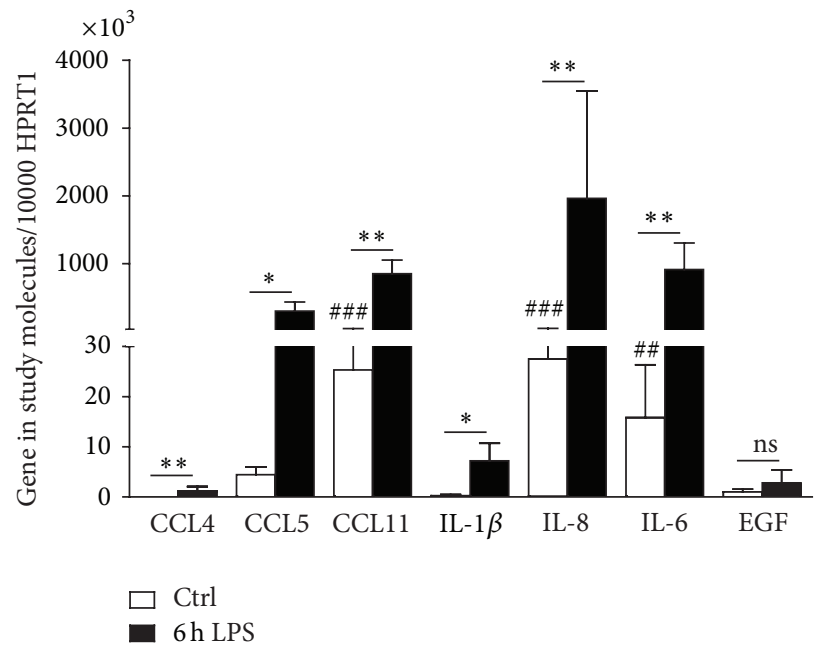

FIGURE 3: Expression of cytokines, chemokines, and growth factors in BJ cells, under homeostatic and inflammatory conditions. Cells were plated at $8 \times 10^{5}$ cells/dish in $60 \mathrm{~mm}$ dishes in a final volume of $6 \mathrm{~mL}$ of medium and treated with $1 \mu \mathrm{g}$ of LPS during $6 \mathrm{~h}$ (LPS), or left untreated $(\mathrm{Ctrl})$, at $37^{\circ} \mathrm{C}$, with $5 \% \mathrm{CO}_{2}$. Total RNA was isolated and retrotranscribed as indicated in Section 2 . The mRNA levels were assessed by quantitative real-time RT-PCR. Gene expression is indicated as genes studied/10 000 molecules of the reference gene HPRT1. Values represent the mean \pm SD from four independent experiments. Kruskall-Wallis test followed by Dunn's posttest statistical analysis was performed between cytokines, chemokines, and growth factor expression under homeostatic and inflammatory conditions $\left({ }^{* *} P<0.01\right.$; $\left.{ }^{* * *} P<0.001\right)$ and among cytokines, chemokines, and growth factor expression under homeostatic conditions $\left({ }^{\# \#}<0.01\right.$; $\left.{ }^{\# \# \#}<0.001\right)$. IL: interleukin; EGF: epidermal growth factor. 


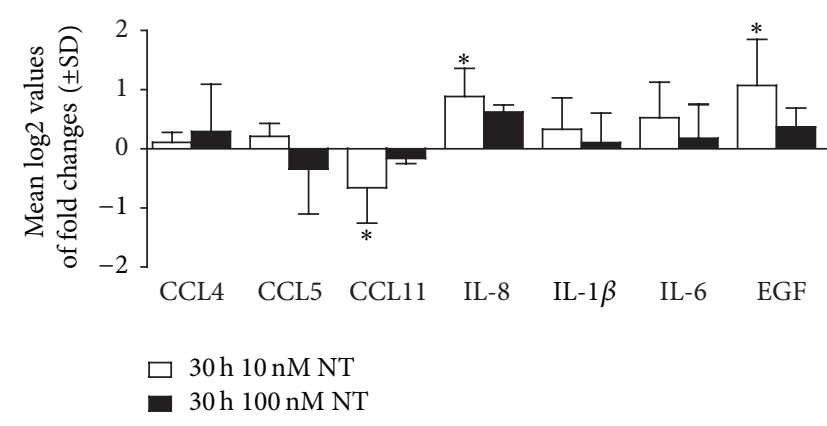

(a)

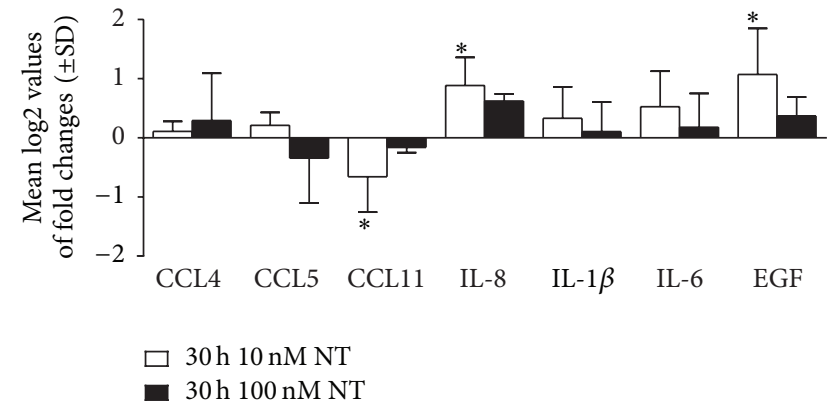

(b)

FIgURE 4: Modulation of gene expression by neurotensin under homeostatic and inflammatory conditions in BJ cells. Cells were maintained in culture medium (Ctrl) and treated with $10 \mathrm{nM}$ of NT (white bars) or $100 \mathrm{nM}$ of NT (black bars) during $30 \mathrm{~h}$ (a) or pretreated with $10 \mathrm{nM}$ (white bars) and $100 \mathrm{nM}$ (black bars) of NT during $24 \mathrm{~h}$ and stimulated with $1 \mu \mathrm{g}$ of LPS during $6 \mathrm{~h}\left(\mathrm{~b}\right.$ ), at $37^{\circ} \mathrm{C}$, with $5 \% \mathrm{CO}_{2}$. Total RNA was isolated and retrotranscribed as indicated in Section 2. The mRNA levels were assessed by quantitative real-time RT-PCR. Gene expression is indicated as mean $\log 2$ values of fold changes relative to the control. Each value represents the mean \pm SD from four independent experiments $\left({ }^{*} \mathrm{P}<0.05\right.$; Kruskall-Wallis test followed by Dunn's posttest statistical analysis between 10 and $100 \mathrm{nM}$ of NT, 10, and $100 \mathrm{nM}$ of NT with the corresponding control, under homeostatic and inflammatory conditions).

LPS, the expression levels of all these genes were highly upregulated, including the expression of chemokine CCL5 $\left({ }^{*} P<0.05\right)$, IL- $1 \beta\left({ }^{*} P<0.05, n=4\right)$, CCL4 $\left({ }^{* *} P<0.01\right.$, $n=4)$, CCL11 $\left({ }^{* *} P<0.01, n=4\right)$, IL-8 $\left({ }^{* *} P<0.01, n=4\right)$, and IL- $6\left({ }^{* *} P<0.01, n=4\right)$, relative to nonstimulated cells (Figure 3), reinforcing the role of fibroblasts as skin immunomodulators.

3.3. Modulation of Gene Expression in Fibroblast by Neurotensin. To evaluate the effect of neurotensin on key inflammatory cytokines and chemokines, BJ cells were incubated with the neuropeptide alone, or with the inflammatory stimulus of LPS alone, or were incubated with the combination of both neurotensin and LPS (Figure 4). Indeed, cells were treated with (1) either 10 or $100 \mathrm{nM}$ of NT for $30 \mathrm{~h}$; (2) incubated with LPS alone for $6 \mathrm{~h}$; (3) incubated with either 10 or $100 \mathrm{nM}$ of NT for $24 \mathrm{~h}$ before an additional stimulus of LPS for $6 \mathrm{~h}$; or (4) left untreated (control). To understand the role of neurotensin in the skin, specifically in skin fibroblasts, cells were subjected to different neurotensin concentrations $(10$ and $100 \mathrm{nM})$ in and out of an inflammatory environment (LPS stimulus). In fact, to better comprehend the role of neurotensin in an inflammatory environment, cells were firstly pretreated with NT and subsequently stimulated with LPS. Furthermore, this protocol may simulate an in vivo NT treatment immediately after an injury (before inflammation starts). After these incubation periods, total RNA was isolated, quantified, and reverse-transcribed to cDNA to finally perform real-time RT-PCR.

BJ cells treated with NT $(10 \mathrm{nM})$ significantly increased the expression of EGF and IL- 8 by $1.07 \pm 0.45-\left({ }^{*} P<0.05\right.$, $n=3)$ and $0.88 \pm 0.48-\left({ }^{*} P<0.01, n=3\right)$ fold above control, respectively, while decreased CCL4 expression by $-0.59 \pm 0.27-\left({ }^{*} P<0.01, n=3\right)$ fold below the control (Figure 4(a)). However, neither the cytokine nor the chemokine profile of these cells showed significant differences in expression when cells were incubated with $100 \mathrm{nM}$ of NT (Figure 4(a)). However, when cells were pretreated with NT ( $10 \mathrm{nM}$ ) during $24 \mathrm{~h}$ followed by a $6 \mathrm{~h}$ LPS stimulus, both the cytokine and chemokine profiles of these cells were significantly modulated. When cells were stimulated with both $10 \mathrm{nM}$ of NT and LPS, the expression of CCL4 was significantly decreased by $0.59 \pm 0.28-\left({ }^{*} P<0.05, n=3\right)$ fold, relative to the control, as shown in Figure 4(b). In addition, when cells were incubated with $100 \mathrm{nM}$ of NT plus LPS, the expression of cytokines IL-6 was significantly reduced by $1.09 \pm 0.87\left({ }^{*} P<0.05, n=4\right)$, relative to cells treated with NT $(10 \mathrm{nM})$. In contrast, the chemokine CCL11 showed a significant increase in expression of $0.65 \pm 0.43-\left({ }^{*} P<0.05\right.$, $n=3)$ fold relative to cells treated with NT $(10 \mathrm{nM})$. Furthermore, EGF expression was significantly increased by $0.99 \pm 0.785-\left({ }^{*} P<0.05, n=3\right)$ fold relative to the control (Figure 4(b)). In conclusion, we observed that, in the presence of neurotensin $(10 \mathrm{nM})$, BJ cells presented a decrease in CCL11 chemokine expression and an increase in IL-8 cytokine expression. Under inflammatory conditions and in the presence of neurotensin, BJ cells presented a decrease in CCL4 and IL-6, while an increase in CCL-11 expression. Furthermore EGF expression was increased in cells incubated with NT either alone or in combination with LPS.

\section{Discussion}

BJ cells expressed the NTR1 and NTR3; NTR1 was located at the cell membrane, cytoplasm, and nucleus while NTR3 was exclusively located in the nucleus. As NTR3 is exclusively localized in the nucleus, its mediated responses can only occur by intracellular neurotensin. Regarding that neurotensin is not expressed by BJ cells, as they do not express NT, NT-NTR3 signalling pathway can only be activated by endocytosed neurotensin previously produced by neighbouring skin cells, such as keratinocytes. Furthermore, NT-NTR3 mediated response will have a later effect in comparison to 
NT-NTR1 mediated response because NTR1 is located at the cell membrane and the activation of this signalling pathway does not require NT internalization. Furthermore, upon NT binding to its receptors, NT activates different signalling pathways and cell responses, such as chemokine and cytokine expression, as previously described by us for a dendritic cell line and by others $[4,9,18-25]$.

Neuropeptides receptor expression under an inflammatory environment has been shown to be regulated by neuropeptides, as observed in rat macrophages for substance $P$ receptors [26] and in HUVECs for NPY receptors [27]. Indeed, we determined if the expression of neurotensin receptors differed in an inflammatory environment and, after cell exposure to LPS, the gene expression of NTR1 was induced while the expression of NTR3 decreased. These results suggest that the upregulation of neurotensin receptors in an inflammatory environment (LPS) will lead to a rise on NT-mediated effects and propagation of NT signalling pathways. Although endogenous NT was not expressed in BJ cells, exogenous NT produced by neighbouring cells can play an important role in NTR activation.

Regarding NT effects on the immunomodulatory function of BJ cells, NT downregulated the immunomodulatory ability of BJ cells under inflammatory conditions and significantly upregulated EGF expression, a crucial growth factor involved in cell growth and wound healing $[28,29]$.

Under homeostatic conditions, exogenous NT was able to significantly upregulate IL-8 and downregulate CCL11 in these cells. These cytokines are involved in the important process of immune cell recruitment to the site of inflammation [30]. IL-8 is a neutrophil-activating cytokine which induces chemotaxis and the release of granule enzymes [31] while CCL11 (or eotaxin) is an important eosinophil chemoattractant which also recruits basophils, Th2 lymphocytes, and tryptase-chymase mast cells [32-35]. Since fibroblasts orchestrate and respond to inflammatory cascades, NT upregulation of IL-8 could activate neutrophils while downregulation of CCL11 chemokine expression could decrease leukocyte recruitment in homeostatic conditions.

Under an inflammatory environment (LPS treatment), NT seemed to have the opposite effect in respect to chemokine/cytokine profile, significantly downregulating the chemoattractant CCL4 and proinflammatory cytokine IL6. Meanwhile, NT also upregulated CCL11. Besides being a chemoattractant, CCL11 may also induce eosinophil degranulation [36] and IgE-independent degranulation of basophils [37], promoting adaptive immune responses, through the selective recruitment of Th2 lymphocytes, which is dependent on the expression of CCR 4 and CCR 8 on Th2 cells [38]. Indeed, the increased expression of CCL11 mediated by NT in fibroblasts could be involved in a Th2 polarized response.

Considering epidermal growth factor, a cell growth and wound healing growth factor, its expression was significantly enhanced, which is in accordance with our previous study performed in dendritic cells [12]. In fact, this same effect was already observed in granulation fibroblasts by the neuropeptide substance P [39]. EGF increase may potentially be triggering autocrine effects on $\mathrm{BJ}$ cells as well as paracrine effects on keratinocytes, by modulating epidermal proliferation and differentiation [40], also emphasising the importance of the EGF effect in the wound closure of wound healing $[28,29]$.

\section{Conclusion}

These results report the effect of exogenous NT under both homeostatic (without LPS) and inflammatory conditions (with LPS) in BJ cells. Under inflammatory conditions, NT was able to downregulate the chemoattractant function of fibroblasts, vital for the last phases of wound healing, which include its migration-proliferation and remodelling phases. Downregulation of chemokines triggered by exogenous NT could decrease the inflammatory status of the wound and could beneficially promote migration of fibroblasts to the wound site, with consequent expression of ECM proteins, important for skin repair. Furthermore, EGF-mediated effects on fibroblasts and keratinocytes will be fulcra for the remodelling phase of wound healing.

Indeed, delayed wounds like diabetic wound healing, characterized by a proinflammatory cytokine profile [1], could potentially be treated with NT, promoting the transition of the inflammatory phase to the last phases of wound healing, thus improving wound healing. Overall our results suggest that neurotensin may be of great value in therapeutic approaches for inflammatory skin diseases, through promoting wound healing. However, our in vitro model has limitations and treatment of fibroblasts in vitro with NT may not mimic its biological processes in their native environment, not taking into account the neuroendocrine, for example, sympathetic and parasympathetic, control of tissues. Thus, these findings should be confirmed with in vivo experiments. Meanwhile, we can hypothesize that in vivo NT administration, under similar conditions, may promote a decreased inflammatory response through these cells, which may be important in the later phases of healing. In vivo studies are needed to further confirm the potential application of NT as a therapy for diabetic foot ulcers.

\section{Abbreviations}

$\begin{array}{ll}\text { NT: } & \text { Neurotensin } \\ \text { IL: } & \text { Interleukin } \\ \text { EGF: } & \text { Epidermal growth factor } \\ \text { ECM: } & \text { Extracellular matrix } \\ \text { WH: } & \text { Wound healing } \\ \text { LPS: } & \text { Lipopolysaccharide } \\ \text { CNS: } & \text { Central nervous system } \\ \text { NTR: } & \text { Neurotensin receptor } \\ \text { GPCRs: } & \text { G protein coupled receptors } \\ \text { TNF: } & \text { Tumor necrosis factor } \\ \text { BCA: } & \text { Bicinchoninic acid } \\ \text { PVDF: } & \text { Polyvinylidene difluoride } \\ \text { ECF: } & \text { Enhanced chemifluorescence } \\ \text { DEPC: } & \text { Diethyl pyrocarbonate } \\ \text { DMEM: } & \text { Dulbeccos Modified Eagle Medium } \\ \text { RT-PCR: } & \text { Reverse transcription polymerase chain } \\ & \text { reaction } \\ \text { HPRT-1: } & \text { Hypoxanthine phosphoribosyltransferase }\end{array}$

HPRT-1: Hypoxanthine phosphoribosyltransferase 1. 


\section{Conflict of Interests}

The authors declare that there is no conflict of interests regarding the publishing of this paper.

\section{Acknowledgments}

The authors thank Paula Marques and João Malva (Life Sciences Department and Center for Neurosciences and Cell Biology, Coimbra University, Portugal) for the kind gift of the BJ cell line. They acknowledge Dr. Francisco Ambrósio for his laboratories facilities during one part of this work and Dr. Carlos Duarte for the availability of the RT-PCR equipment. They also thank Ana Tellechea and Ermelindo Leal for their help in cell culture procedures, as well as Vera Godinho for the collaboration in setting up the RNA extraction experiments. They acknowledge the financial support of SFRH/BD/60837/2009 (Liane Moura), SFRH/BD/30563/2006 (Bruno Miguel Neves), EFSD/JDRF/ Novo Nordisk European Programme in Type 1 Diabetes Research (Eugénia Carvalho), Fundação para a Ciência e Tecnologia PTDC/SAU-MII/098567/2008 (Eugénia Carvalho), and Sociedade Portuguesa de Diabetologia (Eugénia Carvalho).

\section{References}

[1] L. da Silva, E. Carvalho, and M. T. Cruz, "Role of neuropeptides in skin inflammation and its involvement in diabetic wound healing," Expert Opinion on Biological Therapy, vol. 10, no. 10, pp. 1427-1439, 2010.

[2] A. Tellechea, E. Leal, A. Veves, and E. Carvalho, "Inflammatory and angiogenic abnormalities in diabetic wound healing: role of neuropeptides and therapeutic perspectives," The Open Circulation and Vascular Journal, vol. 2, p. 42, 2010.

[3] W. Hartschuh, E. Weihe, and M. Reinecke, "Peptidergic (neurotensin, VIP, substance P) nerve fibres in the skin: immunohistochemical evidence of an involvement of neuropeptides in nociception, pruritus and inflammation," British Journal of Dermatology, vol. 109, no. 25, pp. 14-17, 1983.

[4] J. Donelan, W. Boucher, N. Papadopoulou et al., "Corticotropinreleasing hormone induces skin vascular permeability through a neurotensin-dependent process," Proceedings of the National Academy of Sciences of the United States of America, vol. 103, no. 20, pp. 7759-7764, 2006.

[5] L. K. Singh, X. Pang, N. Alexacos, R. Letourneau, and T. C. Theoharides, "Acute immobilization stress triggers skin mast cell degranulation via corticotropin releasing hormone, neurotensin, and substance P: a link to neurogenic skin disorders," Brain, Behavior, and Immunity, vol. 13, no. 3, pp. 225-239, 1999.

[6] M. Vasiadi, A. Therianou, K. D. Alysandratos et al., "Serum neurotensin (NT) is increased in psoriasis and NT induces vascular endothelial growth factor release from human mast cells," British Journal of Dermatology, vol. 166, no. 6, pp. 13491352, 2012.

[7] T. C. Theoharides, K. D. Alysandratos, and A. Angelidou, "Mast cells and inflammation," Biochimica et Biophysica Acta, vol. 1822, no. 1, pp. 21-33, 2012.

[8] K. Alysandratos, S. Asadi, A. Angelidou et al., "Neurotensin and CRH interactions augment human mast cell activation," PLoS ONE, vol. 7, no. 11, Article ID e48934, 2012.
[9] R. Carraway, D. E. Cochrane, and J. B. Lansman, "Neurotensin stimulates exocytotic histamine secretion from rat mast cells and elevates plasma histamine levels," Journal of Physiology, vol. 323, pp. 403-414, 1982.

[10] D. E. Cochrane, R. E. Carraway, K. Harrington, M. Laudano, S. Rawlings, and R. S. Feldberg, "HMC-1 human mast cells synthesize neurotensin (NT) precursor, secrete bioactive NTlike peptide(s) and express NT receptor NTS1," Inflammation Research, vol. 60, no. 12, pp. 1139-1151, 2011.

[11] M. Ramez, M. Bagot, M. Nikolova et al., "Functional characterization of neurotensin receptors in human cutaneous $\mathrm{T}$ cell lymphoma malignant lymphocytes," Journal of Investigative Dermatology, vol. 117, no. 3, pp. 687-693, 2001.

[12] L. da Silva, B. M. Neves, L. Moura, M. T. Cruz, and E. Carvalho, "Neurotensin downregulates the pro-inflammatory properties of skin dendritic cells and increases epidermal growth factor expression," Biochimica et Biophysica Acta, vol. 1813, no. 10, pp. 1863-1871, 2011.

[13] J. M. Sorrell and A. I. Caplan, "Fibroblast heterogeneity: more than skin deep," Journal of Cell Science, vol. 117, no. 5, pp. 667675, 2004.

[14] R. S. Smith, T. J. Smith, T. M. Blieden, and R. P. Phipps, "Fibroblasts as sentinel cells: synthesis of chemokines and regulation of inflammation," The American Journal of Pathology, vol. 151, no. 2, pp. 317-322, 1997.

[15] R. K. Winkelmann, "The cutaneous innervation of human newborn prepuce.," The Journal of Investigative Dermatology, vol. 26, no. 1, pp. 53-67, 1956.

[16] A. K. Antony, W. Kong, and H. P. Lorenz, "Upregulation of neurodevelopmental genes during scarless healing," Annals of Plastic Surgery, vol. 64, no. 2, pp. 247-250, 2010.

[17] B. M. Neves, M. T. Cruz, V. Francisco et al., "Differential roles of PI3-Kinase, MAPKs and NF- $\kappa \mathrm{B}$ on the manipulation of dendritic cell Th1/Th2 cytokine/chemokine polarizing profile," Molecular Immunology, vol. 46, no. 13, pp. 2481-2492, 2009.

[18] R. Goldman, Z. B. Shavit, and D. Romeo, "Neurotensin modulates human neutrophil locomotion and phagocytic capability," FEBS Letters, vol. 159, no. 1-2, pp. 63-67, 1983.

[19] I. Lemaire, "Neurotensin enhances IL-1 production by activated alveolar macrophages," Journal of Immunology, vol. 140, no. 9, pp. 2983-2988, 1988.

[20] J. J. Garrido, R. M. Arahuetes, A. Hernanz, and M. De la Fuente, "Modulation by neurotensin and neuromedin $\mathrm{N}$ of adherence and chemotaxis capacity of murine lymphocytes," Regulatory Peptides, vol. 41, no. 1, pp. 27-37, 1992.

[21] I. Castagliuolo, C. Wang, L. Valenick et al., "Neurotensin is a proinflammatory neuropeptide in colonic inflammation," Journal of Clinical Investigation, vol. 103, no. 6, pp. 843-849, 1999.

[22] S. Martin, J. Vincent, and J. Mazella, "Involvement of the neurotensin receptor-3 in the neurotensin-induced migration of human microglia," Journal of Neuroscience, vol. 23, no. 4, pp. 1198-1205, 2003.

[23] D. Zhao, S. Kuhnt-Moore, H. Zeng, J. S. Wu, M. P. Moyer, and C. Pothoulakis, "Neurotensin stimulates IL-8 expression in human colonic epithelial cells through Rho GTPase-mediated NF- $\kappa \mathrm{B}$ pathways," The American Journal of Physiology-Cell Physiology, vol. 284, no. 6, pp. C1397-C1404, 2003.

[24] E. Dicou, J. P. Vincent, and J. Mazella, "Neurotensin receptor3/sortilin mediates neurotensin-induced cytokine/chemokine expression in a marine microglial cell line," Journal of Neuroscience Research, vol. 78, no. 1, pp. 92-99, 2004. 
[25] S. F. Assimakopoulos, C. D. Scopa, V. N. Nikolopoulou, and C. E. Vagianos, "Pleiotropic effects of bombesin and neurotensin on intestinal mucosa: not just trefoil peptides," World Journal of Gastroenterology, vol. 14, no. 22, pp. 3602-3603, 2008.

[26] K. L. Bost, S. A. L. Breeding, and D. W. Pascual, "Modulation of the mRNAs encoding substance $\mathrm{P}$ and its receptor in rat macrophages by LPS," Regional Immunology, vol. 4, no. 2, pp. 105-112, 1992.

[27] A. P. Silva, C. Cavadas, B. Baïsse-Agushi, O. Spertini, H. R. Brunner, and E. Grouzmann, "NPY, NPY receptors, and DPP IV activity are modulated by LPS, TNF- $\alpha$ and IFN- $\kappa$ in HUVEC," Regulatory Peptides, vol. 116, no. 1-3, pp. 71-79, 2003.

[28] J. Grzybowski, E. Ołdak, and M. K. Janiak, "Local application of G-CSF, GM-CSF and EGF in treatment of wounds," Postępy Higieny i Medycyny Doświadczalnej, vol. 53, no. 1, pp. 75-86, 1999.

[29] M. Jost, C. Kari, and U. Rodeck, "The EGF receptor-an essential regulator of multiple epidermal functions," European Journal of Dermatology, vol. 10, no. 7, pp. 505-510, 2000.

[30] C. Esche, C. Stellato, and L. A. Beck, "Chemokines: key players in innate and adaptive immunity," Journal of Investigative Dermatology, vol. 125, no. 4, pp. 615-628, 2005.

[31] M. Baggiolini, A. Walz, and S. L. Kunkel, "Neutrophil-activating peptide-1/interleukin 8, a novel cytokine that activates neutrophils," The Journal of Clinical Investigation, vol. 84, no. 4, pp. 1045-1049, 1989.

[32] E. A. Garcia-Zepeda, M. E. Rothenberg, R. T. Ownbey, J. Celestin, P. Leder, and A. D. Luster, "Human eotaxin is a specific chemoattractant for eosinophil cells and provides a new mechanism to explain tissue eosinophilia," Nature Medicine, vol. 2, no. 4, pp. 449-456, 1996.

[33] U. Forssmann, M. Uguccioni, P. Loetscher et al., "Eotaxin2, a novel CC chemokine that is selective for the chemokine receptor CCR3, and acts like eotaxin on human eosinophil and basophil leukocytes," Journal of Experimental Medicine, vol. 185, no. 12, pp. 2171-2176, 1997.

[34] F. Sallusto, C. R. Mackay, and A. Lanzavecchia, "Selective expression of the eotaxin receptor CCR3 by human T helper 2 cells," Science, vol. 277, no. 5334, pp. 2005-2007, 1997.

[35] A. de Paulis, F. Annunziato, L. di Gioia et al., "Expression of the chemokine receptor CCR3 on human mast cells," International Archives of Allergy and Immunology, vol. 124, no. 1-3, pp. 146150, 2001.

[36] T. Fujisawa, Y. Kato, H. Nagase et al., "Chemokines induce eosinophil degranulation through CCR-3," Journal of Allergy and Clinical Immunology, vol. 106, no. 3, pp. 507-513, 2000.

[37] M. Uguccioni, C. R. Mackay, B. Ochensberger et al., "High expression of the chemokine receptor CCR3 in human blood basophils. Role in activation by eotaxin, MCP-4, and other chemokines," The Journal of Clinical Investigation, vol. 100, no. 5, pp. 1137-1143, 1997.

[38] S. J. Ono, T. Nakamura, D. Miyazaki, M. Ohbayashi, M. Dawson, and M. Toda, "Chemokines: roles in leukocyte development, trafficking, and effector function," Journal of Allergy and Clinical Immunology, vol. 111, no. 6, pp. 1185-1199, 2003.

[39] X. Lai, Z. Wang, L. Wei, and L. Wang, "Effect of substance P released from peripheral nerve ending on endogenous expression of epidermal growth factor and its receptor in wound healing," Chinese Journal of Traumatology, vol. 5, no. 3, pp. 176179, 2002.
[40] Y. Shirakata, "Regulation of epidermal keratinocytes by growth factors," Journal of Dermatological Science, vol. 59, no. 2, pp. 73$80,2010$. 


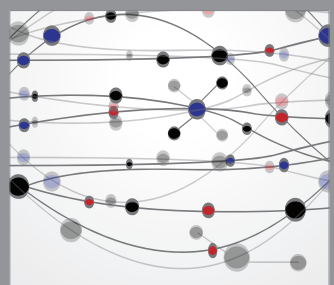

The Scientific World Journal
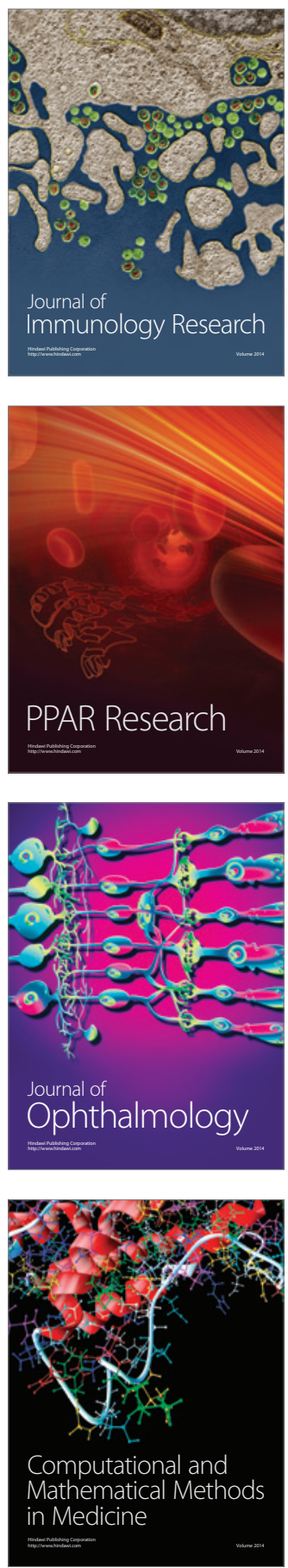



Gastroenterology

Research and Practice
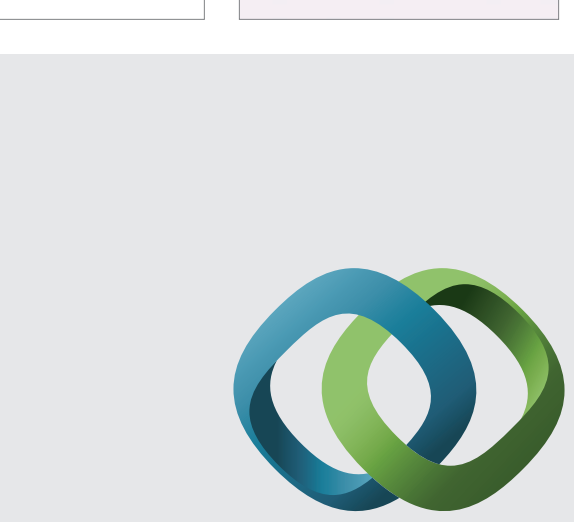

\section{Hindawi}

Submit your manuscripts at

http://www.hindawi.com
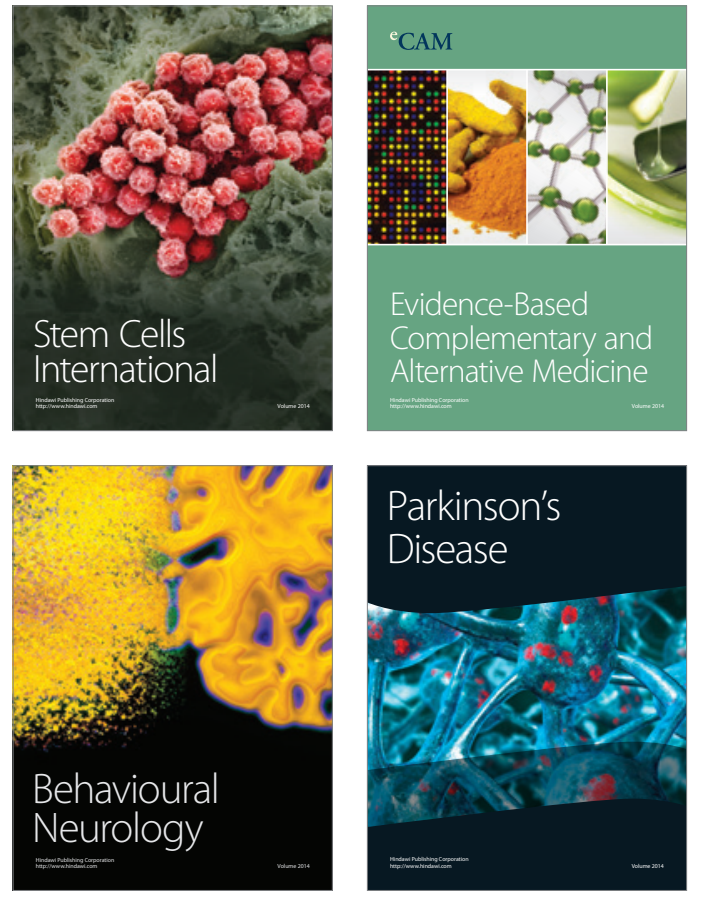
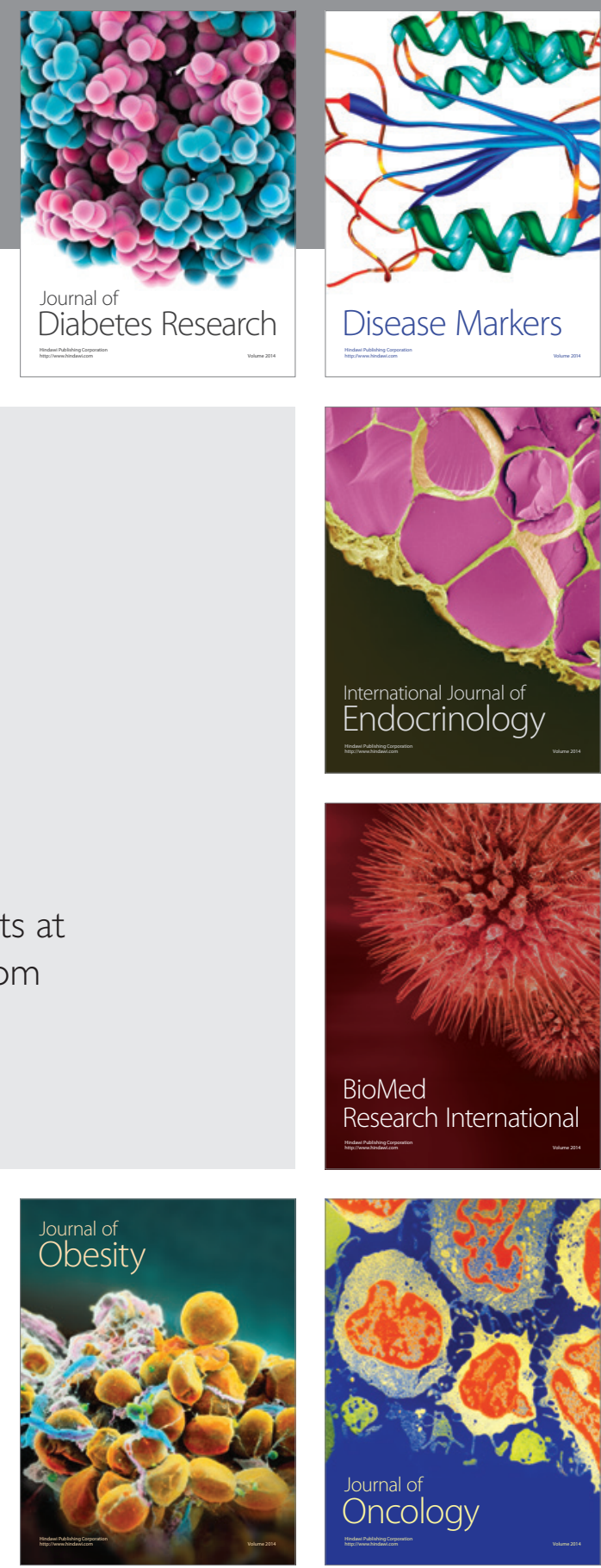

Disease Markers
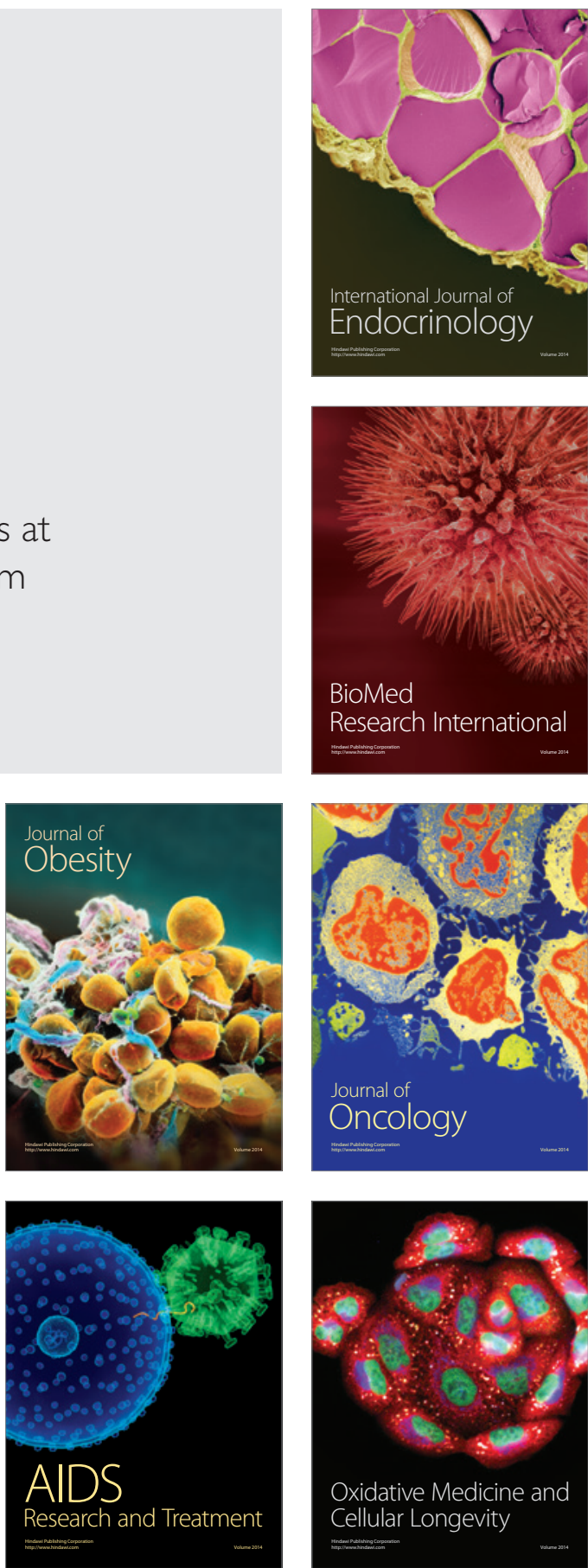